\title{
Adolescent Sexuality and Reproductive Health in two Oil Producing Communities in Imo and Rivers States, Nigeria ${ }^{1}$
}

Ifeoma M. Isiugo-Abanihe International Center for Edu. Evaluation Institute of Edu., Univ. of Ibadan Ibadan, Nigeria
\& Uche C. Isiugo-Abanihe

Faculty of the Social Sciences, Univ. of Ibadan Nigeria uche.abanihe@mail.ui.edu.ng

\section{ABSTRACT}

The Study was conducted in two contiguous oil producing rural local government areas in Imo State and Rivers State of Nigeria, to examine adolescent sexuality and reproductive health situation in the area given its peculiarities. This is a baseline study for an intervention project aimed at identifying strategies for achieving behavioural changes among the youth, and for promotion of health-seeking behaviour for the control of HIV/AIDS and other sexually transmitted infections (STIs). Data were collected through questionnaires administered among 725 students in secondary schools and 249 school drop-outs, comprising 483 females and 491 males. The questionnaire generated ample information on knowledge, attitudes and practices of the youth with respect to sexuality and reproductive health as well as various background characteristics of the respondents. Supplementary qualitative data were collected through focus group discussions. The study found a high level of sexual activity among both in-school and out-of-school adolescents, low levels of knowledge of preventive measures, negotiation skills and STIs, and relatively high levels of premarital pregnancy, abortion and incidence of STIs. The paper proffered suggestions for introducing life-building skills and sexuality education in the secondary schools through peer health education and other school programs, and underscored the need to make schooling more interesting and attractive to the youth.

Keywords: oil producing, adolescent pregnancy, sexual behaviour, abortion, reproductive health

\footnotetext{
${ }^{1}$ The study was funded by the John D. and Catherine T. MacArthur Foundation institutional grant awarded to the Centre for Population Activities and Education for Development (CEPAED), to which the authors are associated. The contribution of other CEPAED Associates, especially Prof Yemi Adekunle, Dr Oka Obono, Dr EBJ Iheriohanma and Dr Ododo, is highly appreciated.
} 


\section{INTRODUCTION}

Sexuality is a multidimensional concept, which encompasses sexual meanings, identities, desire, orientations and pleasure as well as types of partnerships and sexual acts (Berer, 1998; Dixon-Mueller, 1993). It goes beyond concerns related to behaviour, numbers of sexual partners and practices, to the underlying social, cultural and economic factors that make individuals vulnerable to risk and affect the way in which sex is sought, desire and/or refused by young people (de Francisco et al., 2007). For sundry reasons the sexual health of the youth in Nigeria, or their state of physical, emotional, mental and social well-being related to sexuality, leaves much to be desired, especially against the backdrop of the HIV/AIDS epidemic. Therefore, as adolescents undergo the transition from childhood to adulthood, the provision of sexuality information, education and services becomes imperative to ensure a solid foundation of sexual health throughout their life course.

The National Reproductive Health Policy and Strategy (FMH, 2001) has observed that "the reproductive health status of the Nigerian adolescent is poor". According to the document, "paramount among the factors responsible for the current high levels of reproductive illhealth among adolescents are the observations that for many reasons, the average age at first intercourse had declined and there is a greater practice of unprotected sexual intercourse with multiple and casual partners by both boys and girls" (FMH, 2001:7). As Kiragu has noted, "Of the over 60 million people who have been infected with HIV in the past 20 years, about one half became infected between the ages of 15 and 24. Today nearly 12 million young people are living with HIV/AIDS. Young women or girls are several times more likely than young men or boys to be infected with HIV. In nearly 20 African countries (including Nigerian) 5 percent or more women ages 15 to 24 are infected" (Kiragu, 2001:1). With 5 about percent prevalence, HIV has become generalized among the youth in Nigeria. Such a statistic underscores the urgent need to address HIV/AIDS, and reproductive health generally, among the youth.

The 2003 NDHS reveals that about 8 percent of males aged 1519 , and more than 20 percent of girls of the same age group, have had sex by exact age of 15 years (NDHS, 2004). The female median age at first sexual intercourse was 16.2 year and 16.7 years for those aged 25- 
Ifeoma M. Isiugo-Abanihe $\mathcal{E}$ Uche C. Isiugo-Abanihe: Adolescent Sexuality and Reproductive Health in two Oil Producing Communities in Imo and Rivers States, Nigeria

49 and 20-49 respectively. Young people are mostly affected by the HIV/ AIDS epidemics. In 1998, 60 percent of the 20,334 reported AIDS cases in Nigeria were within the age group 15-24 years (FRH, 2001), the majority of whom were women who live in the social environment of male domination or female subjugation (IsiugoAbanihe, 2003).

This age group also suffers disproportionately from other sexually transmitted infections (STIs) because they are more likely to have multiple, short-term and casual relationships, often as a means of sustenance. Their vulnerability is also heightened because they tend to lack sufficient information and understanding of STIs, and are less likely to have the requisite skills and capability to negotiate for safer sex. Family Health International (FHI, 2001) has identified a wide range of individual, social and cultural factors, termed risk protective factors, which influence the sexual and reproductive behaviour of young people, as follows:

- Individual characteristics, including knowledge, attitudes, beliefs, values, motivation and experience;

- Peer and sexual partners with whom they interact;

- Families and adults in the community;

- Institutions such as schools, workplaces, and religious organizations;

- Communities through which social expectations about gender norms, sexual behaviours, marriage and childbearing is transmitted.

These concerns motivated CEPAED to design the project entitled Integrated Family Life Education (IFLE), a holistic intervention program targeted on in-school and out-of school youth, aged 10-24 years, in two neighbouring LGAs, Ohaji-Egbema LGA of Imo State and ONELGA in Rivers state. These two LGAs have a lot in common. First, they are socio-culturally related and linguistically similar, being separated by an imaginary political boundary which, nevertheless, allows for free interaction of people from either side. Secondly, the two LGAs have a sizable amount of oil exploration, with the accompanying gas flaring, soil and water pollution, and other environmental problems. Thirdly, the operations of oil companies have attracted migrant workers, nationals and non- 
nationals, to the area, to which women of fortune and the youth also tend to gravitate.

\section{OBJECTIVES}

The study set out to accomplish the following objectives:

- Ascertain the level of sexual activity among in-school and outof-school adolescents aged 13-24.

- Determine the prevalence of unwanted pregnancy, childbearing, abortion, sexually transmitted infections and other reproductive health problems among adolescents in the area.

- Assess the level and pattern of reproductive health (including HIV/AIDS) knowledge, attitude and behaviour of young people.

- Identify cultural/traditional practices that affect adolescent sexuality, reproductive health and rights.

- Assess the effect of the socio-cultural and environment contexts on girls' education and quality of life of adolescents and young adults.

- Identify strategies for achieving behavioural changes among the youth, and for promotion of health-seeking behaviour for the control of HIV / AIDS and other STIs.

\section{METHODOLOGY}

Two main research methods, survey research and focus group discussion, were utilized in collecting the baseline data for the study, which are analyzed in the present paper. A total of one thousand questionnaires were administered to respondents in eight communities in ONELGA and Ohaji/Egbema LGAs. Eight secondary schools in the communities were purposefully selected for the study, and a random sample of out-of-school adolescents were selected from these communities for comparison. Of the 1000 questionnaires that were distributed, 974 were found usable. Among these, students in secondary schools in the communities comprise 725, while 249 were 
Ifeoma M. Isiugo-Abanihe $\mathcal{E}$ Uche C. Isiugo-Abanihe: Adolescent Sexuality and Reproductive Health in two Oil Producing Communities in Imo and Rivers States, Nigeria

out-of-school (school drop-outs); in all, 483 females and 491 males were interviewed in the study. The questionnaire generated ample information on knowledge, attitudes and practices of the youth with respect to sexuality and reproductive health as well as various background characteristics of the respondents.

A total of 20 FGDs were conducted in seven communities. In each of them, except in one, 3 FGDs were conducted, comprising one adult group (male or female), girls (in-school or out-of-school), and boys (in-school or out-of-school). Altogether, 220 participants were involved in 20 FGD sessions, which discussed the situation of the youth with respect to their sexual behaviour, family life, schooling, the environment and their perception on many other issues. Participants in each of the 20 groups ranged from 9 to 11 people; and the discussions were facilitated by trained moderators, assisted by note-takers.

\section{RESULTS}

\section{Background Characteristics}

Table 1 displays selected background characteristics of the adolescents interviewed in the baseline study. Roughly 50 percent of them are in the 17-19 age group, and about one-quarter apiece below 17 and above 19 years of age. About one-quarter of the respondents are out-of-school or dropped out of school. Indeed, the drop-out rate in the area is high, and this is attributed to a number of factors including inability of many parents to provide the requisite tuition fees and other school requirements, the unattractiveness of the schooling experience, and the high level delinquency, peer distractions and truancy. Among girls, pregnancy is mentioned as an important reason for dropping out of school as well as heavy and demanding domestic chores and farm work which they are expected to perform.

The majority of the respondents come from monogamous homes, although about two-fifths come from polygynous homes, an indication of a relatively high level of polygyny in these communities relative to about 20 percent level of polygyny recorded in the 1999 Nigeria Demographic and Health Survey (NDHS) for the southeast 
zone of Nigeria to which these locations belong. The people of OhajiEgbema and ONELGA communities are predominantly Christians, with Roman Catholic and Pentecostal religious groups as the two most dominant denominations. Table 1 shows that farming is the major occupation of the people, especially among women 60 percent of whom are farmers in Ohaji-Egbema and 40 percent in ONELGA. Other major occupations are civil service (which includes teachers) and trading.

Only about 5 percent of adolescents in Ohaji-Egbema and 14 percent of those in ONELGA reported fathers who work in the oil companies operating in the area. Mothers are rarely reported to work in the oil business. The higher proportion of oil workers in ONELGA is probably an indication of more active operation of the oil companies in that place relative to Ohaji-Egbema. It should be observed that the generally low level of local personnel in the oil companies, as revealed in this study, lends credence to the charges of deliberate exclusion from employment levelled against the oil companies by the communities and civil society organizations in the area. It is significant that outright unemployment is rare in these communities. People rarely go about seeking for employment, because the area provides little opportunities for school leavers.

Table 1: Percent distribution of adolescents by selected background characteristics by research location

\begin{tabular}{|l|c|c|c|c|}
\hline \multirow{2}{*}{ Variables } & \multicolumn{2}{|l|}{ OHAJI-EGBEMA } & \multicolumn{2}{c|}{ ONELGA } \\
\cline { 2 - 5 } Age of Respondent: & & & & Male \\
Below 17 years & 20.7 & 26.8 & 30.8 & 27.7 \\
17 - 19 years & 51.4 & 54.6 & 36.0 & 45.8 \\
20 yrs and above & 26.6 & 18.3 & 28.5 & 25.4 \\
NR & 1.3 & 0.3 & 4.7 & 1.1 \\
\hline Current Class: & & & & \\
SS1 & 21.9 & 22.9 & 23.3 & 19.8 \\
SS2 & 22.3 & 22.9 & 19.8 & 19.8 \\
SS3 & 33.5 & 30.4 & 21.1 & 28.2 \\
Out-of-school & 22.3 & 23.9 & 27.9 & 32.2 \\
\hline Type of Family: & & & & \\
Monogamy & 60.2 & 64.4 & 58.7 & 58.8 \\
Polygamy & 39.8 & 35.6 & 41.3 & 51.2 \\
\hline Religious Affiliation: & & & & \\
\hline
\end{tabular}


Ifeoma M. Isiugo-Abanihe \& Uche C. Isiugo-Abanihe: Adolescent Sexuality and Reproductive Health in two Oil Producing Communities in Imo and Rivers States, Nigeria

\begin{tabular}{|l|r|r|r|r|}
\hline Roman Catholic & 51.1 & 43.1 & 17.4 & 20.3 \\
Protestant & 15.4 & 19.3 & 14.5 & 14.7 \\
Pentecostal & 21.3 & 26.5 & 45.9 & 48.6 \\
White Garment & 4.3 & 5.6 & 3.5 & 4.0 \\
Traditional & 3.1 & 0.3 & 5.2 & 2.3 \\
Muslim & 0.0 & 0.7 & 0.0 & 0.0 \\
No Religion & 0.9 & 2.0 & 5.8 & 4.5 \\
Other & 3.5 & 2.6 & 8.6 & 5.6 \\
\hline Father's Occupation: & & & & \\
Farming & 43.9 & 38.2 & 31.4 & 19.8 \\
Trading & 9.4 & 17.3 & 15.1 & 18.1 \\
Artisan/Craft & 3.4 & 2.3 & 8.7 & 10.2 \\
Civil Service/White & 20.7 & 23.5 & 15.7 & 14.1 \\
Collar & & & & \\
Professional & 4.7 & 3.6 & 4.1 & 3.4 \\
Oil Worker & 6.0 & 4.9 & 15.1 & 13.6 \\
Unemployed & 0.3 & 1.3 & 2.9 & 2.8 \\
Other & 6.3 & 4.6 & 5.2 & 16.4 \\
NR & 5.3 & 4.2 & 1.7 & 1.7 \\
\hline Mother's Occupation: & & & & \\
Farming & 52.4 & 79.4 & 46.5 & 32.8 \\
Trading & 14.4 & 14.7 & 19.8 & 18.0 \\
Artisan/Craft & 4.4 & 2.6 & 2.9 & 6.2 \\
Civil Service/White & 20.1 & 28.4 & 23.8 & 29.4 \\
Collar & & & & \\
Professional & 0.6 & 1.6 & 1.7 & 2.8 \\
Oil Worker & 0.6 & 0.3 & 0.0 & 0.0 \\
Unemployed & 1.9 & 0.3 & 2.3 & 2.3 \\
Other & 5.6 & 6.9 & 2.9 & 8.5 \\
\hline Total number & 319 & 306 & 172 & 177 \\
\hline
\end{tabular}

\section{Sexual Behaviour}

Table 2 presents information on the level of sexual activity among adolescents in the two project locations. High levels of sexual activity are evident in the Table; about 54 percent of male adolescents in Ohaji-Egbema and 62 percent of females are sexually experienced. The corresponding figures for ONELGA are 49 percent and 54 percent respectively. The figures suggest higher level of sexual activity among 
females relative to males, an indication that some of their sexual partners come from the older male population.

The mean age of first sex is roughly 16 years, slightly higher among girls than boys. The female mean age of first sex in excess of 16 years is comparable to the national figures of 16.6 years derived from the 1999 NDHS (Isiugo-Abanihe and Oyediran, 2004) and 16.7 in 1990 (Isiugo-Abanihe, 1994). Generally the first sexual partners of female adolescents are older by about 4 years, whereas the first sexual partners of male respondents are younger or of the same age. This finding suggests two different patterns of sexual initiation among males and females. The former have their sexual debut with school friends and neighbourhood peers, whereas girls could have their first sexual encounter with mates in the school or neighbourhood as well as older men or even teachers who would have enticed or lured them with material things.

Among those who are sexually experienced, about 44 percent of boys and 48 percent of girls in Ohaji-Egbema, and 60 percent of boys and 62 percent of girls in ONELGA had had sex in the last 4 weeks, with the mean number of affairs at about 1.3 and 2.7 in OhajiEgbema and ONELGA respectively. It is noteworthy that close to 30 percent of sexually experienced boys and 21 percent of girls in ONELGA have had four or more sexual acts in the 4 weeks preceding the survey, an average of once a week. 
Table 2: Percent distribution of adolescents by selected measures of sexual activity by research location

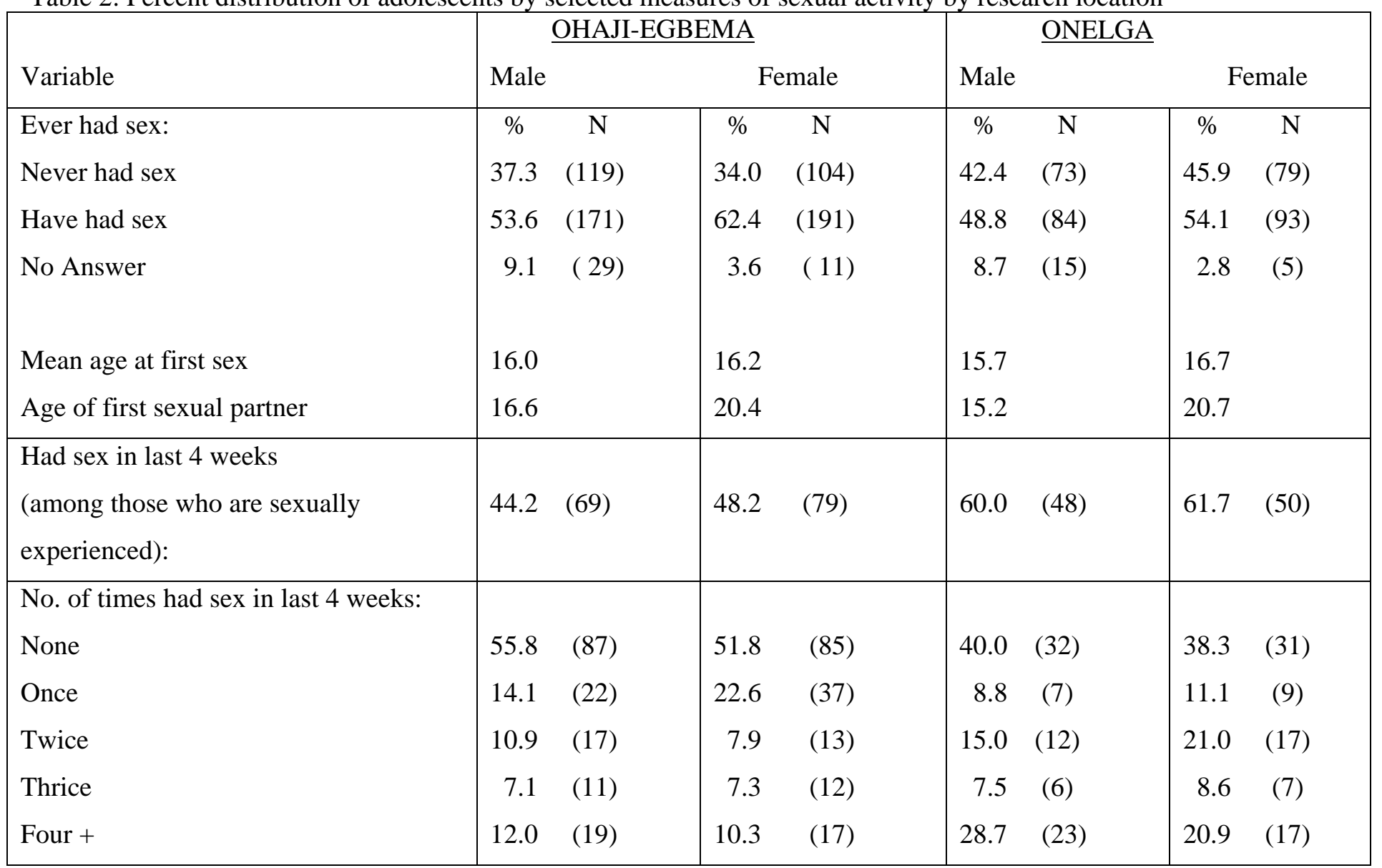




\begin{tabular}{|c|c|c|c|c|c|c|c|c|}
\hline Mean no. of sex in past 4 weeks & 1.3 & & 1.2 & & 2.7 & & 2.7 & \\
\hline $\begin{array}{l}\text { One } \\
\text { Two } \\
\text { Three } \\
\text { Four + } \\
\text { Mean no. of sexual partners in last } 3 \\
\text { months }\end{array}$ & $\begin{array}{r}52.6 \\
26.3 \\
7.4 \\
13.7 \\
\\
2.3\end{array}$ & $\begin{array}{l}(50) \\
(25) \\
(7) \\
(13)\end{array}$ & $\begin{array}{r}69.1 \\
10.3 \\
2.9 \\
17.7\end{array}$ & $\begin{array}{l}(47) \\
(7) \\
(2) \\
(12)\end{array}$ & $\begin{array}{r}37.5 \\
23.4 \\
7.8 \\
31.4\end{array}$ & $\begin{array}{c}(24) \\
(15) \\
(5) \\
(20)\end{array}$ & $\begin{array}{r}69.6 \\
15.2 \\
10.9 \\
4.4\end{array}$ & $\begin{array}{l}(32) \\
(7) \\
(5) \\
(2)\end{array}$ \\
\hline $\begin{array}{l}\text { Last time had sex: } \\
\text { Today/Yesterday } \\
\text { A few days ago } \\
\text { A week ago } \\
\text { Last month } \\
\text { Other answers }\end{array}$ & $\begin{array}{r}5.5 \\
16.6 \\
12.3 \\
39.9 \\
25.8\end{array}$ & $\begin{array}{l}(20) \\
(65) \\
(42)\end{array}$ & $\begin{array}{l}18.2 \\
14.5 \\
15.1 \\
33.3 \\
18.9\end{array}$ & $\begin{array}{l}\text { (24) } \\
\text { (53) } \\
(30)\end{array}$ & $\begin{array}{r}9.4 \\
27.1 \\
23.5 \\
20.0 \\
20.0\end{array}$ & $\begin{array}{l}(8) \\
(23) \\
(20) \\
(17) \\
(17)\end{array}$ & $\begin{array}{l}12.6 \\
17.2 \\
19.5 \\
24.1 \\
26.4\end{array}$ & $\begin{array}{l}(11) \\
(15) \\
(17) \\
(21) \\
(23)\end{array}$ \\
\hline
\end{tabular}

56 
Ifeoma M. Isiugo-Abanihe \& Uche C. Isiugo-Abanihe: Adolescent Sexuality and Reproductive Health in two Oil Producing Communities in Imo and Rivers States, Nigeria

Table 3 shows the level of sexual activity among the three age groups of the youth, as well as for in-school and out-of-school adolescents. First, the Table indicates that female level of sexual activity is generally higher than that of males, especially in OhajiEgbema. This suggests substantial female choice of sexual partners outside the adolescent population. Secondly, as expected, sexual activity increases with age in the two communities. For instance, about 48 percent of adolescent girls below 17 years of age have had sex compared with 62 percent of those age 17-19 years and about 88 percent of those 20-24 years. The corresponding sexual activity figures for ONELGA are 34.7, 44.4 and 84.4 percent. The same pattern of monotonic increase with age is evident among male adolescents.

Table 3: Percent distribution of adolescents who are sexually experienced by age, schooling status by location

\begin{tabular}{|l|c|c|c|c|}
\hline & \multicolumn{2}{|l|}{ OHAJI-EGBEMA } & \multicolumn{2}{c|}{ ONELGA } \\
\cline { 2 - 4 } & Males & Females & Males & Females \\
\hline Age Group: & & & & \\
\hline Below 17 years & 39.4 & 47.6 & 13.2 & 34.7 \\
\hline 17-19 years & 48.2 & 61.7 & 59.7 & 44.4 \\
\hline 20-24 years & 75.3 & 87.5 & 73.5 & 84.4 \\
\hline Schooling status: & & & & \\
\hline In-school & 49.6 & 56.2 & 33.1 & 35.0 \\
\hline Out-of-school & 67.6 & 82.2 & 89.6 & 89.5 \\
\hline Total & 171 & 191 & 84 & 93 \\
\hline
\end{tabular}

Thirdly, it is evident from the Table that in-school youth have a considerably lower level of sexual activity relative to their out-ofschool counterparts. For instance, while nearly 50 percent of in-school males in Ohaji-Egbema are sexually experienced, about 68 percent of their out-of-school brothers are so experienced. The gap between inschool and out-of-school males in ONELGA is even wider. It is pertinent to note that whereas the levels of sexual activity among outof-school youth are higher in ONELGA, those of in-school adolescents are higher in Ohaji-Egbema.

\section{Adolescent Pregnancy, Abortion and Childbearing}

Modern contraceptive methods have the dual advantage of protection from pregnancy and infection from sexually transmitted 
diseases. Clearly, abstinence offers the surest protection from pregnancy, but where a substantial proportion of young people could neither abstain nor use contraceptives, then pregnancy results with its accompanying outcomes namely, abortion and childbirth.

Table 4 shows that knowledge of any contraceptive method is fairly high among the youth of Ohaji-Egbema and ONELGA, especially those from the latter location. However, the proportion who have ever used any method is much lower, and current use of methods is even lower. Out-of-school adolescents exhibit both higher levels of awareness of contraception as well as higher levels of use. The most commonly known and used method is the condom, having been used by about 27 percent of males and 16 percent of females in Ohaji-Egbema and 42.4 percent of males and 26 percent of females in ONELGA. About one-third of out-of-school male youth in OhajiEgbema relative to one-fifth of their in-school brothers have ever used the condom; female out-of-school have 37 percent prevalence rate relative to about 10 percent for in-school female youth. For ONELGA, the condom prevalence rates for the four categories of youth are 66.7, 33.1, 50.9 and 14.2 percent respectively.

We asked sexually active youths whether or not they used a method of pregnancy prevention during their last sexual act. Overall, about 40 percent of them did not use any method during their last sex. Among those who claimed to have used a method, the condom is the most prevalent method used. In fact, the figures in Table 4 suggest a fairly high prevalence of contraceptives among the youth in the project area, a product probably of past family planning campaign in the area on account of heavy presence of migrant oil men. 
Table 4: Percent distribution of adolescents by knowledge and use of contraceptives by location

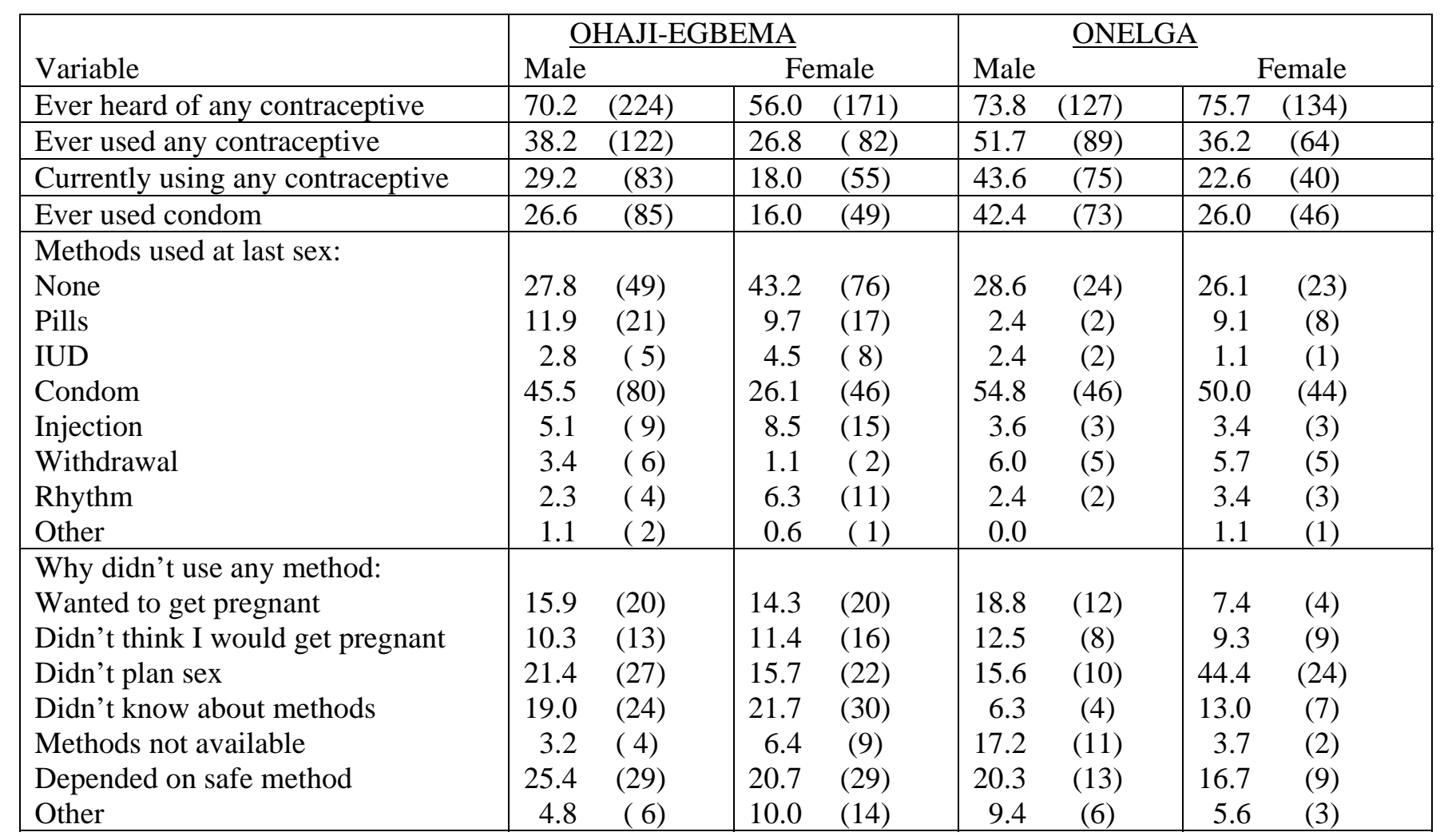


Conversely, we asked those who did not use any method in their last sexual encounter why they did not. As Table 4 indicates, most of those who did not use any method of contraceptives failed to do so because they did not plan to have the particular sexual encounter or because they depended on the calculation of their safe periods. A substantial number failed to use a method because they wanted to get pregnant or because they did not think the particular sexual act would result in a pregnancy. It is noteworthy that about 20 percent of the youths in Ohaji-Egbema failed to use contraceptives because they did not know about methods; the number of those ignorant of contraceptive methods is lower in ONELGA, where many however claimed that the methods are not available to them. Given the high level of sexual activity among the youth in Ohaji-Egbema and ONELGA, and the relatively low level of contraceptive use among the youth, it is imperative to examine the prevalence of pregnancy, abortion and childbearing among adolescent girls in the two research areas. This is accomplished in Table 5.

Table 5: Percent distribution of female adolescents by pregnancy and abortion status by location

\begin{tabular}{|l|cc|cc|}
\hline Variable & \multicolumn{3}{|c|}{ OHAJI-EGBEMA } & \multicolumn{2}{l|}{ ONELGA } \\
\hline Ever been pregnant: & \multicolumn{4}{|c|}{} \\
Yes & 16.7 & $(51)$ & 15.8 & $(28)$ \\
No & 83.3 & $(255)$ & 84.2 & $(65)$ \\
\hline How many times pregnant in & & & & \\
last 2 years (among those & & & & \\
ever pregnant): & & & & \\
One & 52.9 & $(27)$ & 53.6 & $(15)$ \\
Two & 13.7 & $(7)$ & 21.4 & $(6)$ \\
Three & 3.9 & $(2)$ & 0.0 & \\
No answer & 29.4 & $(15)$ & 25.0 & $(7)$ \\
\hline Ever aborted: & & & & \\
Yes & 43.1 & $(22)$ & 17.9 & $(5)$ \\
No & 56.9 & $(29)$ & 46.4 & $(13)$ \\
No answer & 0.0 & & 35.7 & $(10)$ \\
\hline Ever had a live birth: & \multicolumn{4}{|c|}{} \\
Yes & 54.9 & $(28)$ & 57.1 & $(16)$ \\
No & 45.1 & $(23)$ & 42.9 & $(12)$ \\
\hline
\end{tabular}


Ifeoma M. Isiugo-Abanihe $\mathcal{E}$ Uche C. Isiugo-Abanihe: Adolescent Sexuality and Reproductive Health in two Oil Producing Communities in Imo and Rivers States, Nigeria

About 17 percent of female adolescents age 10-24 years in Ohaji-Egbema and 16 percent of those in ONELGA reported to have ever been pregnant. Whereas about 55 percent of out-of-school girls in Ohaji-Egbema have even been pregnant, 43 percent of those in ONELGA have conceived; however, the figures are substantially lower for in-school girls at 5 percent and 14 percent respectively. Among sexually experienced adolescents the overall premarital pregnancy figures are 30 percent in Ohaji-Egbema and 33.3 percent in ONELGA. This is consistent with, even if lower than, the high rate of premarital pregnancy found in Nembe (35.6 percent of all girls interviewed), another oil-producing location in the Niger Delta region (Isiugo-Abanihe et al., 2002). Among those who have been pregnant, 17.6 percent of those in Ohaji-Egbema and about 21.4 percent of those in ONELGA have had at least two pregnancies in the previous two years. More than 40 percent of ever pregnant female adolescents in Ohaji-Egbema and 18 percent of those in ONELGA have aborted a pregnancy, and more than 50 percent claimed to have had a live birth. These figures are higher that comparable data for the country as a whole, and constitute strong justification for intervention activities among the youth in the area whose future is being adversely affected by premarital pregnancy, abortion and childbearing.

\section{Sexually Transmitted Infections}

Table 6 presents data on knowledge and incidence of sexually transmitted infections (STIs) among the youth in Ohaji-Egbema and ONELGA. Overall, sexually transmitted infections are not well known in the area. Gonorrhoea, the best identified STI, is known by only 50 percent of Ohaji-Egbema youths, and about 64 percent of those in ONELGA. The Table shows that infection with STIs is fairly high, more so among males than females, and among the youth of ONELGA relative to those in Ohaji-Egbema. Gonorrhoea is the most prevalent STI, about twice higher among males than females. Table 6 indicates that about 36 percent of sexually experienced males in OhajiEgbema and nearly 20 percent of their female counterparts have ever been infected with an STI. The corresponding figures for ONELGA are much higher - 65.6 percent and 33.3 percent respectively. The most common sexually transmitted infection among the youth in the two research locations are gonorrhoea and genital warts. 
Treatment for STIs among the youth in these two areas is mainly unprofessional, with services mostly provided through selfmedication, chemist shops and traditional healers. This gives rise to the possibility of imperfect or incomplete healing which results in a high likelihood of re-infection, with a more lasting damage to the reproductive system.

Table 6: Percent distribution of adolescent by knowledge and incidence of sexually transmitted infections by location

\begin{tabular}{|c|c|c|c|c|}
\hline \multirow[b]{2}{*}{ Variable } & \multicolumn{2}{|c|}{ OHAJI-EGBEMA } & \multicolumn{2}{|c|}{ ONELGA } \\
\hline & Male & Female & Male & Female \\
\hline Knows any STI & $64.3(205)$ & $54.6(167)$ & $68.6(118)$ & $79.1(140)$ \\
\hline STI Known: & & & & \\
\hline Gonorrhoea & $52.4(167)$ & 46.7 (143) & $62.8(108)$ & $65.0115)$ \\
\hline Syphilis & $28.2(90)$ & $20.3(62)$ & 30.2 (52) & 23.7 (42) \\
\hline Pubic lice & $20.7(66)$ & $16.0(49)$ & 19.2 (33) & 27.1 (48) \\
\hline Genital warts & $24.5(78)$ & 19.3 ( 59) & 34.3 (59) & $26.6(47)$ \\
\hline Other STI & 18.5 ( 59) & $6.5(20)$ & $17.4(30)$ & $40.7 \quad(72)$ \\
\hline $\begin{array}{l}\text { Suffered from any } \\
\text { STI among } \\
\text { sexuallyexperienced }\end{array}$ & $35.7(61)$ & $19.4(37)$ & $65.5(55)$ & $33.3(31)$ \\
\hline $\begin{array}{l}\text { STI suffered from: } \\
\text { Gonorrhoea }\end{array}$ & $15.8 \quad(27)$ & $6.3 \quad(12)$ & $39.3 \quad(33)$ & 17.2 \\
\hline Syphilis & $4.7 \quad(8)$ & $2.6 \quad(5)$ & $6.0 \quad(5)$ & $2.2 \quad(2)$ \\
\hline Pubic lice & 7.6 (13) & $4.7 \quad(9)$ & 9.5 & 7.5 \\
\hline Genital warts & 11.1 (19) & $11.0 \quad(21)$ & $31.0 \quad(26)$ & $8.6 \quad(8)$ \\
\hline Other STI & 9.9 (17) & $4.2(8)$ & $3.6 \quad(3)$ & $12.9(12)$ \\
\hline
\end{tabular}

\section{Myths/Misconceptions/Cultural Beliefs}

The survey data revealed a high level of misconceptions and myths that are likely to influence young people's sexuality and reproductive health behaviour. Table 7 summaries these misconceptions, myths and beliefs expressed by the respondents on sexuality, reproductive health and rights issues. Close to 70 percent of the youth agreed that providing information about sexuality and reproductive health increases sexual activity. Nearly 50 percent of the respondents believe that having sex for money is acceptable, and about one in three believes pregnancy outside the home is all right. 
Ifeoma M. Isiugo-Abanihe \& Uche C. Isiugo-Abanihe: Adolescent Sexuality and Reproductive Health in two Oil Producing Communities in Imo and Rivers States, Nigeria

More than one-half of the respondents agree that a boy or a man cannot stay with one sexual partner.

Table 7: Distribution of respondents' views on myths, misconceptions and cultural beliefs about sexuality and reproductive health

\begin{tabular}{|l|c|c|c|c|}
\hline \multicolumn{1}{|c|}{ Misconception } & \multicolumn{3}{c}{$\begin{array}{l}\text { \% of Agreement with Misconceptions } \\
\text { Ohaji/Egbema }\end{array}$} \\
\cline { 2 - 5 } & M & F & M & F \\
\hline $\begin{array}{l}\text { 1. Providing information } \\
\text { about sexuality and } \\
\text { reproductive health } \\
\text { increases sexual activity }\end{array}$ & 69 & 68 & 73 & 64 \\
\hline $\begin{array}{l}\text { 2. Having sex to get money } \\
\text { or things you need is okay }\end{array}$ & 53 & 48 & 48 & 31 \\
\hline $\begin{array}{l}\text { 3. Pregnancy outside } \\
\text { marriage is okay }\end{array}$ & 39 & 36 & 29 & 23 \\
\hline $\begin{array}{l}\text { 4. A boy or man cannot stay } \\
\text { with one sexual partner }\end{array}$ & 59 & 57 & 57 & 49 \\
\hline $\begin{array}{l}\text { 5. Use of condom to prevent } \\
\text { pregnancy and diseases } \\
\text { should not be encouraged }\end{array}$ & 29 & 38 & 23 & 24 \\
\hline $\begin{array}{l}\text { 6. Women opinions are not } \\
\text { important in making } \\
\text { decisions about sex and } \\
\text { having babies }\end{array}$ & 62 & 49 & 57 & 58 \\
\hline $\begin{array}{l}\text { 7.It is wrong for a girl to } \\
\text { refuse sex from her boy } \\
\text { friend }\end{array}$ & 55 & 55 & 64 & 57 \\
\hline $\begin{array}{l}\text { 8. Going to the Chemist or } \\
\text { buy medicine to have an } \\
\text { abortion is a good way of } \\
\text { having abortion }\end{array}$ & 55 & 55 & 51 & 47 \\
\hline $\begin{array}{l}\text { 9. A girl who refuses sex } \\
\text { from her boy-friend } \\
\text { deserves to be beaten }\end{array}$ & 51 & 48 & 52 & 36 \\
\hline $\begin{array}{l}\text { 10. If a girl is raped because } \\
\text { of her "stubbornness" it is } \\
\text { not any body's business }\end{array}$ & 60 & 71 & 49 & 48 \\
\hline Total & 302 & 299 & 172 & 177 \\
\hline
\end{tabular}


The foregoing shows that many myths and misconceptions about young peoples' sexuality and reproductive health abound. These negative views, which seem to stem from their background orientation of male dominance, have serious implication for sexuality and reproductive health education, especially for the empowerment of girls. It is particularly important to note that there are strong views in support of sexual abuse of girls and these are most likely based on the expected gender-stereotypical role of girls to be submissive to their male partners. It is also interesting to note that the male respondents supported the strongly negative views (e.g. in items 7, 9 and 10) more than the girls did. This shows a high level of gender insensitivity by the boys. Gender bias in favour of males is also evident in item 4 which excuses boys' sexual permissiveness, and implicitly their irresponsibility. There is obviously a strong need for educational intervention to correct the misconceptions by providing accurate information to both males and females.

\section{Sexual Activity by Background Factors}

Table 8 shows that adolescents who live with both parents are generally less likely to engage in early sexual activity. Irrespective of gender and location, those who live with only one parent or with people who are not their parents are more likely to engage in sexual activity. For instance, more female adolescents in Ohaji/Egbema who live with their fathers only or with other persons have had sex. Seventy-seven percent of females in ONELGA who live with other people have had sex.

By the same token, adolescents whose parents are divorced or widowed, or were never married are more likely to engage in sexual relation. Apart from male adolescents in ONELGA, all other categories of respondents reveal lower incidence of sexual activity among those whose parents are married and living together. Furthermore, adolescents from polygynous homes are more likely to be sexually active relative to those from monogamous homes. For instance, about 63 percent of males and 62 percent of females in ONELGA who are from polygynous homes have had sex. The corresponding figures for those from monogamous homes are 47 percent and 49 percent respectively. 
Ifeoma M. Isiugo-Abanihe \& Uche C. Isiugo-Abanihe: Adolescent Sexuality and Reproductive Health in two Oil Producing Communities in Imo and Rivers States, Nigeria

The Table also indicates that the level of sexual activity among adolescents rises as the level of their mother's education falls. For all categories of adolescents, those whose mothers have no schooling or only some primary education have higher incidence of sexual intercourse, while those whose mothers have some secondary or tertiary education have lower level of sexual activity. There does not seem to be a significant and consistent pattern of variation in sexual activity by religious affiliation. However, it appears that those who belong to white-garment churches, Roman Catholic and other religions are more likely to have had sexual relation than others. Pentecostal Christians are less sexually active, but even then, close to or more than 50 percent of them have had sex. This finding implies that religious injunctions against pre-marital sex or fornication are not strictly adhered to by adolescents in the two study locations, especially in Ohaji/Egbema, and particularly among female adolescents.

Table 8: Distribution of adolescents who have had sex by selected background factors by gender

\begin{tabular}{|l|l|l|l|l|}
\hline \multirow{2}{*}{ Background factors } & \multicolumn{2}{|c|}{ Ohaji/Egbema } & \multicolumn{2}{l|}{ ONELGA } \\
\cline { 2 - 5 } & Male & Female & Male & Female \\
\hline 1. Who they live with: & & & & \\
Father and Mother & 53.3 & 61.5 & 45.7 & 51.6 \\
Mother only & 60.0 & 57.9 & 78.3 & 47.2 \\
Father only & 53.8 & 84.6 & 58.3 & 33.3 \\
Other persons & 82.1 & 83.3 & 70.5 & 77.4 \\
All respondents & 58.7 & 64.7 & 54.1 & 54.4 \\
\hline 2. Parents marital status: & & & & \\
Married and living together & 54.5 & 63.5 & 44.1 & 55.4 \\
Married but not living together & 57.1 & 63.6 & 56.3 & 63.6 \\
Divorced or widowed & 73.9 & 72.7 & 83.3 & 51.2 \\
They are never married & 80.0 & 50.0 & 50.0 & 47.1 \\
All respondents & 59.2 & 64.3 & 53.2 & 54.1 \\
\hline 3. Type of home: & & & & \\
Monogamous & 55.4 & 66.0 & 47.3 & 48.5 \\
Polygamous & 64.3 & 62.6 & 63.7 & 62.3 \\
All respondents & 59.0 & 64.7 & 53.8 & 54.1 \\
\hline 4. Mother's education: & & & & \\
$\quad$ No Schooling & 77.2 & 68.8 & 74.4 & 61.0 \\
\hline
\end{tabular}


African Population Studies Vol. $22 n^{\circ} 2$ /Etude de la Population Africaine Vol. $22 N^{\circ} 2$

\begin{tabular}{|l|l|l|l|l|}
\hline Some primary & 63.8 & 69.0 & 58.2 & 56.1 \\
Some secondary & 52.2 & 62.1 & 39.5 & 44.2 \\
Some tertiary & 44.7 & 52.9 & 20.0 & 45.0 \\
All respondents & 60.4 & 65.3 & 53.5 & 53.3 \\
\hline 5. Religious affiliation: & & & & \\
Roman Catholic & 58.2 & 68.0 & 62.1 & 48.6 \\
Protestant & 61.7 & 60.0 & 45.0 & 48.0 \\
Pentecostal & 58.7 & 57.5 & 50.7 & 54.8 \\
White Garment & 51.1 & 70.6 & 66.7 & 57.1 \\
Others & 56.3 & 83.3 & 60.7 & 65.0 \\
All respondents & 58.7 & 64.4 & 54.5 & 53.8 \\
\hline
\end{tabular}

\section{VIEWS FROM FOCUS GROUP DISCUSSIONS}

\section{Perceptions of Sexual Activity}

The focus group discussion threw more light into these results. There was a consensus that sexual activity is initiated earlier 'nowadays' (from age 9 to 12) than a decade or more ago when sexual initiation took place from 18 to 20 years. The focus groups discussed the ideal age for sexual debut among girls, which reveals clear generational divide. Whereas the youth opined that sexual debut among girls should be 15 to 18 years, FGDs among adults settle for much higher age of 20 to 25 years or at the time of marriage. Terms such as 'promiscuous', 'wayward', and 'loose' were used to describe the current pattern of sexual relationship among the youth. Young persons and adults alike confessed that the situation is out of control, and that boys and girls keep multiple sexual partners with little concern with the views of their parents. The following extracts portray the disquieting increase in sexual activity as perceived by FGD participants:

An in-school girl from Awara:

Many girls go out of their parents' houses every evening parading the streets, looking for boys. Boys also feel free to 'perform' (have sex) even in homes of their girl friends. Parents feel helpless. They can't do anything to help their girls.

A male Community Leader from Assa: 
Ifeoma M. Isiugo-Abanihe \& Uche C. Isiugo-Abanihe: Adolescent Sexuality and Reproductive

Health in two Oil Producing Communities in Imo and Rivers States, Nigeria

In the evening, around the market, they walk around looking for sex partners. If you try to advise them, they abuse you.

A girl from Assa:

It (sexual activity) is too rampant here. You can't see a girl in the evening sitting in her father's house. Every night, they will go out looking for boys. Even the boys would carry the girl to their father's house.

A boy from Okwuzi:

The youths here are engaged a lot in sexual movement because of the way girls dress. Girls dress attractive and immediately you see such a thing, if you are a potent man, you will have the feeling .... and you will go to the girl and appeal to her; immediately she agrees for you, you now have sex with her.

Below is an excerpt from FGD among Mothers from Awara: 1st Participant:

It (sexual activity among young people) is very common. They (young people) don't respect it at all.

2nd Participant:

At 11 O'clock in the night, you will see them doing it in this hall (an old dilapidated school building).

3rd Participant: Some do it also in the bush.

$4^{\text {th }}$ Participant: Some even do it in the church.

Given the unanimous agreement of high level of sexual activity among the youth, it is not surprising that pregnancy, abortion and childbearing were equally reported to be widespread. Whereas abortion was strongly condemned by most participants (with the exception of a few young persons, mostly males), early childbearing seemed permissible. Indeed, some parents explained that the early sexual activity is partly related to their culture of early marriage. A 
participant from Aggah (a mother) laments to the approval of other participants:

When some of girls are sent to school, they will get pregnant and come back because in this place, people believe in early marriage. You will see a girl of 12, you will put her in school, before 2 to 3 months, she will get pregnant and drop out.

With respect to abortion, there is a clear indication from the FGDs that young people are choosing it as a better option to avert the effects of early pregnancy. In many of the communities, abortion is a daily occurrence, with many girls reported to have had multiple abortions. In fact, one out-of-school male participant reported seeing an aborted foetus in a gutter right outside our FGD meeting venue. In Awara, abortion was so rampant that women imposed heavy sanctions against any girl who was reported to have procured an abortion. Although some of the participants claimed that this action had slightly reduced the frequency of abortion in Awara and Assa communities, others observed that the problem has remained unabated. What had happened was that more secrecy and caution were applied.

An equally important observation was that the apparent reduction in abortion did not necessarily result from an increase in the use of pregnancy prevention methods, hence reduction in rate of pregnancy. This may not be unconnected with the fact that many young unmarried women in communities in Ohaji/Egbema LGA and ONELGA, particularly in Awara and Asaa, did not have much problem carrying their babies; so, instead of more abortion, there was more child bearing, even among girls who were so visibly poor and malnourished that they and their babies appeared completely wasted.

The FGD yielded information on many underlying reasons for early sexual activity and childbearing in the participating communities - Awara, Assa, Obokofia, Mmahu, Okwuzi, Mgbede and Aggah - such as poverty and lack of alternative means of livelihood for the girls, the changing culture of the oil-producing areas, lack of parental care, and custom of early marriage etc.

There was a clear indication from the FGDs that HIV/AIDS was becoming a threat to the lives of people in Ohaji/Egbema and 
Ifeoma M. Isiugo-Abanihe $\mathcal{E}$ Uche C. Isiugo-Abanihe: Adolescent Sexuality and Reproductive Health in two Oil Producing Communities in Imo and Rivers States, Nigeria

ONELGA, and myths and misconceptions about it abound. Although most participants reported not having physically seen people living with AIDS (partly because they confessed that they did not know all the symptoms of identifying them), many reported that some AIDS sufferers from their communities had returned from big cities such as Lagos and Port Harcourt to die in their villages. Participants exhibited ignorance and negative attitude toward some strategies for preventing the spread of HIV/AIDS. Although some claimed to have heard health talks on the radio about prevention strategies, they held strong negative attitude toward young people's use of condom. Although they recognized AIDS as a problem threatening life in oil producing areas, (where they admitted there was a lot of sexual activity and networking), they offered no solutions or strategies for averting impending problems. They only depended on God and hoped that governments and NGOs would find a way out for them. They also expressed support for more community sensitization on HIV/AIDS, and expressed hostility toward victims of AIDs some of whom they believed deliberately spread the disease to others.

\section{Cultural and Traditional Beliefs and Practices}

Many cultural beliefs and attitudes of Ohaji/Egbema and ONELGA people influence young people's sexuality and reproductive health behaviour. Traditionally, discrimination and subordination of females are commonly practiced based on gender division of labour. Women and girls are perceived mainly from the point of view of their sexual and reproductive roles; and since they themselves have internalized the beliefs over time, (that their life's fulfilment depends on whether or not they marry and have children), they seem to devote their lives to the pursuit of that goal. For many of them, as revealed in the FGDs, their main preoccupation, irrespective of their status, is to seek men's attention and engage in sexual acts. Although many participants, including the girls and the parent groups asserted that discrimination against girls no longer existed, both the fathers and boys admitted that if they had to make a choice of whether to have a boy or a girl, or train a boy or girl in school when there is scarcity, they would choose the boy. Some confessed that even though they loved their girls "equally", they would invest more on male children because they were the ones that would continue the family names. 
In addition to rampant pregnancy and childbirth outside marriage, more girls than boys in both ONELGA and Ohaji/Egbema were reported not to have genuine interest in schooling. They lacked self esteem and empowerment. This attitude results, sometimes, in girls being used and maltreated as mere objects of sex, and often abandoned afterwards. Several participants, particularly the parent groups and community leaders, reiterated the belief of Egbema and Ohaji people in early marriage, though many concede that the practice is waning. However, this antecedent of their culture seems to influence current attitudes and behaviour of young people and parents towards unintended pregnancy. Thus, many parents would not have much problem with their young daughters' pregnancy if there is a man to claim the pregnancy. It is a common practice in all the communities for a man to claim ownership of a baby he fathered whether or not he marries the woman.

The FGD participants reported several instances of sexual violence and abuse against young girls. This is perhaps one of the manifestations of gender subordination of females. Rape is particularly common in some of the areas, especially Awara and Assa. The following excerpts give a vivid description of the plight of young women in the area:

1st Girl Participant:

It may be as you are walking on the road, all boys would see you, and call you, say ... Ijeonu (not a real name); and I refuse to come. They will go and tell their fellow boys that this Ijeonu is proving stubborn.

2nd Girl Participant:

They will gather and make sure they catch and rape this Ijeonu.

Young Male Participant from Assa:

Another point to note, which is a problem in my opinion, is the masquerade. They use it to molest the girls and even rape some of them.

A mother from Awara:

About less than a week ago, seven boys raped a 13year old girl here and the girl is still in the hospital. 
Ifeoma M. Isiugo-Abanihe $\mathcal{E}$ Uche C. Isiugo-Abanihe: Adolescent Sexuality and Reproductive Health in two Oil Producing Communities in Imo and Rivers States, Nigeria

The culture of gender subordination of females has many negative effects including limiting their access to financial resources. In both Ohaji/Egbema and ONELGA communities, women complained of being marginalized in the sharing of monetary compensation paid by oil companies operating in the areas. For instance, whereas most young male school drop-outs are alleged to belong to pressure groups (mainly cults) that forcefully obtain money from oil companies and by so doing enrich themselves, most female school drop-outs have to depend on the magnanimity of their boyfriends, or otherwise work long hours in subsistence farming and other low-skill, low-paying jobs.

The poor situation of women and girls in many communities in ONELGA and Ohaji/Egbema and the risks they face as a result of socio-cultural attitudes and practices, call for urgent attention. There is need for enlightenment programmes that aim at making the society more gender-sensitive as well as to empower girls to become more aware of their problems and develop better coping strategies to avert gender subordination.

\section{Effect of Environment}

On-the-spot observations and Focus Group Discussions on issues of safety of environment revealed that there were serious concerns in the area. First, there was a consensus that the environment of Ohaji and Egbema communities had become very much degraded and unsafe due to the side effects of oil-production activities including air and water pollution. It was reported by participants in all the twenty groups that gas flaring and oil spillage into the surrounding rivers and land had caused serious damage to fishes and other sea animals, on the one hand, and farm lands and crops, on the other. Although there were visible evidences of gross environmental pollution in these parts of the Niger Delta (e.g. the continuous scorching heat and blinding smoke from excess gas flaring), the problem of lack of accurate information on the effects, coping strategies and solutions seems to cause even further damage psychologically to the indigenes, especially the illiterate women. Some of them complained about being emotionally and physically damaged by the problems of their environment. They attributed every negative aspect of their lives to gas flaring and oil spillage. Even old women 
who were experiencing joint pains believed that their problem was caused by gas flaring. Young girls supported the opinion of their parents that part of the negative impact of their degraded environment is their mothers' inability to reap bumper harvest from their farms as in the past, and this has exposed them to many hazards of life.

\section{Socio-Cultural Environment, Sexuality and Education}

People are, to a large extent, victims of the social and cultural environment in which they find themselves. In Ohaji/Egbema and ONELGA communities, the social dynamics observable in many oilproducing areas such as Nembe in Bayelsa State can be easily identified. The FGDs, especially those involving parent groups and community leaders, highlighted some unique features of the social context of oil producing communities that tend to promote high sexual activity and reproductive health problems among young people in the area. These include:

- An overwhelming presence of night clubs and their corrupting influence on girls.

- Concentration of large sums of money in the hands of a few men (especially chiefs, and idle, criminally-minded youths).

- Marginalization of women and girls in the sharing of resources from oil and their concomitant exposure to poverty.

- Instability of marriage, polygamous family structure and lack of adequate care for children, especially girls, leading to sexual permissiveness.

- High patronage to cultism, violence, insecurity, and sexual abuse.

- Overwhelming lack of interest in schooling, especially by girls many of whom are preoccupied with the business of exchanging their body for money.

- Disturbing unemployment situation and hopelessness among young people. 
Ifeoma M. Isiugo-Abanihe $\mathcal{E}$ Uche C. Isiugo-Abanihe: Adolescent Sexuality and Reproductive Health in two Oil Producing Communities in Imo and Rivers States, Nigeria

In virtually all the communities, the FGD participants indicted parents for failing in their responsibility to be mentors and role models of good behaviour to their children. This view was supported by many parents who cited several examples to illustrate their case. In Awara, some mothers had these to say about some other parents:

A: It is not only the youths, some fathers when they go to work on their farms also carry girls that they see and sleep with them. Some mothers, when they see good-looking men, they also sleep with them on the farm, so the youths copy from their parents...

$\mathrm{B}$ : It is the strangers that caused it. For instance, when a girl is hired to work on the farm when the wife is not there, the man will sleep with her in the bush. Even some men carry other people's wives into the bush to sleep with them. This is a general thing here...

C: Yes, it is a common thing here. But in my place (where I was married from) when you (a man) sleep with some body's wife, and when people find out, they will beat the two people up very well and they will also pay a fine...

D: There are married women who go out to sleep with men in this place. They actually plead with these men to please sleep with them. The same often happened with the men. So you can see that these children copied from their parents...

The foregoing and more are illustrative of the prevailing sociocultural setting that is unhealthy and hostile to learning and any form of development. The consequences of polygyny, unstable family background particularly lead to a vicious cycle of girls' underschooling and threaten to perpetrate generations of unschooled and unskilled girls, stricken with poverty. The parents and leaders groups regretted the current situation of sexual laxity and lack of positive parental influence in many homes. 


\section{Summary and discussion}

In summary, both the FGD and survey data revealed a yawning gap between knowledge and behaviour among youth in Ohaji/Egbema and ONELGA with respect to their sexuality and reproductive health. The results also showed that there was a marked difference in the level of knowledge about sexual and reproductive behaviour by the in-school and out-of-school population; therefore, intervention programmes for the two groups needed to be carried out separately. The level of sexual activity between young unmarried males and females is worrisome to the entire community members of both the ONELGA and Ohaji/Egbema LGAs. Even though some older members claim that it is related to their past custom of early marriage, they also confess that the practice has set their people back in many indescribable ways.

In addition to the problem of lack of stable homes, many young people also complained about the absence of successful, educated men and women who are interested in their well-being and who can provide leadership to them as role models. Women, especially those in ONELGA lamented that their counterparts who have gone to cities to settle, do not care to come down to the villages to assist them. They pleaded that city dwellers should be invited to come down to assist them to solve some of their problems. It was generally believed that relevant and empowering education was needed to disabuse the minds of the rural indigenes, especially girls and women, from a culture that condones early marriage and childbearing and dependency-driven, male-dictated sexual relationships.

Based on information obtained from all the FGD groups, there is a clear evidence that both young and old people in Egbema/Ohaji and ONELGA communities are seriously concerned about the prevailing situation of sexual networking, unintended pregnancy, childbearing and abortion. Surprisingly, perhaps due to the fact that many have not seen an AIDS victim, there seems to be little or no worry about the impending danger of HIV and AIDS epidemic in the area. The most burdensome problems of both girls and boys, according to the participants, apart from the uncontrolled early sexual activity, and its consequences, are the cyclic problems of unemployment, cultism and violence, poor attendance and 
Ifeoma M. Isiugo-Abanihe $\mathcal{E}$ Uche C. Isiugo-Abanihe: Adolescent Sexuality and Reproductive Health in two Oil Producing Communities in Imo and Rivers States, Nigeria

discontinuation from primary and secondary schooling. These multifacetted problems seem to fuel more and more sexual harassment and violence against girls. Unfortunately, no government, or nongovernmental agencies have sufficiently committed themselves to solving the various problems that have continued to negatively affect the lives of young people in the area.

Children and adolescents in the petroleum-rich Niger Delta region of Nigeria grow up in environments that are dense with explicit and implicit messages, prejudices and stereotypes to sexual and gender identities and their expressions. According to de Francisco et al. (2007), in the process of internalizing these sex-gender rules they adopt attitudes and behaviours that have significant implications for their own and others' health and rights, both currently and in the future. At the same time many of them lack even the most basic information about sec and reproduction; about the physical and emotional changes they are experiencing as they pass through puberty and beyond; and about their personal rights and responsibilities, including the skills they need to protect themselves from unwanted sexual acts and from pregnancy and STIs (IsiugoAbanihe et al. 2002; Varga, 2003).

The importance of education in increasing knowledge and changing behaviour should be stressed against the backdrop of the results of this study. The school is a massive industry that turns out young people, who, in passing through the school system inevitably allow the school to pass through them. Learning or the inculcation of knowledge, as well as character building, are the preoccupation of the school if it should produce youths who are sound both in learning and character. This function is profound; it constitutes the foundation for the society since the products of the school system today are the leaders of tomorrow. Hence, the quality of a nation's future is as good as the children who pass through its school system. It goes without saying, therefore, that the impartation of total or holistic knowledge, which is both vertical and horizontal, mental and intellectual as well as social and cultural, is a sine qua non for the development of the total person, a desirable goal for national development. It is against this background that the introduction of a school-based sexuality and family life education is imperative in the era of HIV and AIDS. The high school drop-out rates in the area also suggests the need to make 
schooling more interesting and attractive to the youth. Both state and local governments have important roles to play in improving the quality of schools as well as ensuring free primary and secondary school education in these volatile areas. Also, as part of their social responsibility and contribution to community development in their areas of operation, the oil companies should institute more proactive school programmes which aim at keeping the youth in school, thereby reducing youth restiveness and preparing them for gainful employment after graduation.

\section{References}

Berer, Marge (ed.), 1998, Sexuality. Thematic Issues of Reproductive Health Matters, 6(12).

De Francisco, Andres, Ruth Dixon-Mueller and Catherine d'Arcangues, 2007. Research Issues in Sexual and Reproductive Health for Low- and Middle-income Countries. Geneva, Switzerland: Global Forum for Health Research and World Health Organization.

Dixon-Mueller, Ruth, 1993, The sexuality connection in reproductive health, Studies in Family Planning, 24(5): 269-282.

Family Health International (FHI), 2002. Intervention Strategies that Work for Youth: Summary of FOCUS on Young Adults, FHI Youth Net, Paper 1, Arlington, VA: USA.

Federal Ministry of Health (FMH), 2001. National Reproductive Health Policy and Strategy. Abuja: FMH.

Isiugo-Abanihe, I M, Uche Isiugo-Abanihe and Ruby Ofrey, 2002. Teenage reproductive health problems in riverine areas of Nigeria: the Nembe experience. In The African Population in the 21st Century, Proceeding of the Third African Population Conference, Durban, South Africa, December 1999. Vol. 5:393-412.

Isiugo-Abanihe, U C., 1994. The correlates of premarital sexuality in Nigeria, African Journal for the Psychological Study of Social Issues, 1(2):257-276. 
Ifeoma M. Isiugo-Abanihe E Uche C. Isiugo-Abanihe: Adolescent Sexuality and Reproductive Health in two Oil Producing Communities in Imo and Rivers States, Nigeria

Isiugo-Abanihe, U.C. 2003. Male Role and Responsibility in Fertility and Reproductive Health in Nigeria. Ibadan: Centre for Population Activities and Education for Development.

Isiugo-Abanihe, U C and Kola Oyediran, 2004. Household socioeconomic status and sexual behaviour among Nigerian female youth. African Population Studies, 19(1):81-98.

Kiragu, Karungari, 2001. Youth and HIV/AIDS: Can We Avoid Catastrophe? Population Reports, Series L, no. 12. Baltimore: The Johns Hopkins University, Bloomberg School of Public Health.

National Population Commission (NPC), 2004. Nigeria Demographic and Health Survey, 2003. Abuja: NPC.

Varga, Christine, 2003. How gender roles influence sexual and reproductive health among South African adolescents, Studies in Family Planning, 34(3): 160-172. 